\title{
Nitrogen Fertigation of Young Navel Oranges: Growth, N Status, and Uptake of Fertilizer $\mathbf{N}$
}

\author{
Tom L. Weinert, Thomas L. Thompson', Scott A. White \\ Department of Soil, Water, and Environmental Science, 1200 E. South Campus \\ Drive, University of Arizona, Tucson, AZ 85721 \\ Michael A. Maurer \\ Plant and Soil Science Department, Texas Tech University, Lubbock, TX 79409
}

Additional index words. fertilization, Citrus sinensis

\begin{abstract}
Microsprinkler irrigation may result in increased efficiency of $\mathrm{N}$ and water application to citrus. However, best management practices (BMPs) have not yet been developed for microsprinkler use, particularly on newly established citrus. Experiments were conducted during 1997-98 in central Arizona to evaluate the effects of $\mathrm{N}$ rate and fertigation frequency on 'Newhall' navel oranges (Citrus sinensis) planted in Mar. 1997. Two experiments were conducted, each with factorial combinations of $\mathrm{N}$ rate (0 to $204 \mathrm{~g}$ / tree/year) and fertigation frequency (weekly to three times per year). In one experiment, nonlabeled $\mathrm{N}$ fertilizer was used, and in the other ${ }^{15} \mathrm{~N}$-labeled fertilizer was used. Trunk diameter, leaf $\mathrm{N}$, and ${ }^{15} \mathrm{~N}$ partitioning in the trees were monitored. During 1997, neither trunk diameter nor leaf $\mathrm{N}$ were affected by $\mathrm{N}$ rate or fertigation frequency. No more than $6 \%$ of $\mathrm{N}$ applied was found in the trees. During 1998, leaf $\mathrm{N}$ in fertilized plots was significantly higher than in nonfertilized plots, but leaf $\mathbf{N}$ in all trees remained above the critical $\mathrm{N}$ concentration of $25 \mathrm{mg} \cdot \mathrm{g}^{-1}$. During 1998, no more than $25 \%$ of the fertilizer $\mathrm{N}$ applied was taken up by the trees. Results suggest that $\mathrm{N}$ applications are not needed during the first growing season after planting for microsprinkler-irrigated citrus in Arizona. Only low rates of $N(\leq 68 \mathrm{~g} /$ tree $/ \mathrm{yr})$ may be needed during the second growing season to maintain adequate tree $\mathrm{N}$ reserves.
\end{abstract}

Citrus production in the southwestern United States is highly dependent on irrigation and $\mathrm{N}$ fertilizer inputs to achieve optimum fruit yield and quality. Growers realize that these inputs must be carefully managed to ensure optimum profits and minimal environmental impacts. Escalating water costs and decreasing water availability are causing growers to adopt production practices that allow them to significantly improve water and $\mathrm{N}$ use efficiency while decreasing labor costs. One such practice is the conversion from surface flood irrigation systems to under-tree microsprinkler irrigation. In addition to allowing precise control of irrigation, microsprinkler systems offer the ability to use high frequency fertigation with fluid $\mathrm{N}$ materials throughout the 9-month growing season. This practice greatly improves the potential for higher $\mathrm{N}$ use efficiency due to decreased leaching losses.

The majority of new citrus plantings in Arizona and southern California are being equipped with microsprinkler irrigation systems except where water and land costs are unusually low. Research on high frequency $\mathrm{N}$ fertigation on citrus has been done in Florida (Marler and Davies, 1990; Willis et al., 1991; Boman, 1996), but little research has been done in the arid and semi-arid west.

Received for publication: 4 Dec. 2000 . Accepted for publication: 9 Aug. 2001.

${ }^{1}$ To whom reprint requests should be addressed. E-mail address: thompson@ag.arizona.edu
Additional research is needed in the desert Southwest to evaluate the effects of fertigation frequency and fluid $\mathrm{N}$ application rate on microsprinkler irrigated citrus. Further, best management practices (BMP) guidelines for optimum fluid $\mathrm{N}$ application frequency and rate are needed for microsprinkler-irrigated citrus to augment existing BMPs for more conventional irrigation methods (Doerge et al., 1991). The movement away from flood irrigation and use of granular $\mathrm{N}$ fertilizer to microsprinklers using exclusively fluid $\mathrm{N}$ sources is a major trend in western citrus production. The objectives of this study were to determine the effects of $\mathrm{N}$ rate and $\mathrm{N}$ fertigation frequency on: 1) trunk diameter and leaf $\mathrm{N}$ concentration of newly planted, microsprinkler-irrigated navel orange trees and; 2) uptake of fertilizer $\mathrm{N}$ into tree roots, stems, and leaves.

\section{Materials and Methods}

Two experiments were conducted at the Univ. of Arizona Citrus Agricultural Center near Phoenix, Ariz. The soil is a Gilman fine sandy loam [coarse-loamy, mixed (calcareous), hyperthermic Typic Torrifluvent]. This soil was formed on an alluvial fan and has a layer of coarse sand and pebbles $\approx 0.9 \mathrm{~m}$ beneath the soil surface. The soil had been fallowed for 9 years since 1988 after a heavy application of manure. To reduce concentrations of residual $\mathrm{NO}_{3}-\mathrm{N}$, sudangrass (Sorghum sudanenses L.) was planted in Summer 1996, cut four times, and the aboveground biomass was removed. Soil organic N was $0.44 \mathrm{mg} \cdot \mathrm{g}^{-1}$ in the surface $0.3 \mathrm{~m}$, which is normal for soils in this area. Soil samples collected before initiation of the experiments showed $\mathrm{NO}_{3}-\mathrm{N}$ concentrations $<4 \mathrm{mg} \cdot \mathrm{kg}^{-1}$ in the surface $0.9 \mathrm{~m}$ (data not shown).

'Newhall' navel oranges (Citrus sinensis) budded to 'Carrizo' citrange rootstock were planted in Mar. 1997 on $3 \times 6$-m centers. Under each tree was one pressure-compensating microsprinkler (Maxijet, Dundee, Fla.) with a $300^{\circ}$ spray pattern, located $5 \mathrm{~cm}$ from the north side of the trunk. The trunks were protected from wetting and sunburn with waxed paper collars. The emitters were equipped with a deflector that limited the wetted radius to $0.6 \mathrm{~m}$. The flow rate was $38 \mathrm{~L} / \mathrm{h}$ at a pressure of $240 \mathrm{kPa}$, which wetted $8 \%$ of the orchard floor. Main and branch irrigation lines were constructed from $12.5 \mathrm{~mm}$ (ID) black polyethylene pipe, and the lines were arranged in order to apply the appropriate treatment to each tree. Irrigation was applied when soil water tension, measured by tensiometers with cups placed at $30 \mathrm{~cm}$ depth, reached $30 \mathrm{kPa}$. Irrigation amounts were intended to replace evapotranspiration, plus a $5 \%$ to $10 \%$ leaching fraction. Totals of $1.23 \mathrm{~m}$ and $1.64 \mathrm{~m}$ of irrigation water (relative to the wetted area) were applied during 1997 and 1998, respectively. Irrigations were as frequent as three times per week during the summer months (Fig. 1). Irrigation water was analyzed periodically throughout the study and contained $<3 \mathrm{mg} \cdot \mathrm{L}^{-1} \mathrm{NO}_{3}-\mathrm{N}$. The orchard floor was kept cultivated and weed free.

Expt. 1. This experiment consisted of nonfertilized control plots and factorial combinations of three fertigation frequencies (weekly, monthly, and three times per year) and three $\mathrm{N}$ rates (Table 1), arranged in a randomized complete-block design with five replications. Each plot contained two trees. All $\mathrm{N}$ was applied as urea ammonium nitrate solution (UAN 32-0-0) through the irrigation system. The $\mathrm{N}$ fertilizer was applied to each treatment by using a Dosatron fertilizer injector (Dosatron Products, Sunnyvale, Fla.). The irrigation lines were flushed for at least $10 \mathrm{~min}$. after fertigation. Fertigation began on 16 Mar. and ended on 15 Nov. 1997 and began 1 Mar. and ended 1 Nov. 1998. Threetimes-yearly plots were fertigated during March, June, and August of each year. Preplant soil tests indicated that all other essential plant nutrients were present in adequate quantities.

Tree response to $\mathrm{N}$ rate and fertigation frequency was measured by leaf $\mathrm{N}$ concentration and trunk growth. Thirty fully expanded spring-flush leaves were collected from each plot in August of each year. Leaf tissue was rinsed with distilled water, dried at $65^{\circ} \mathrm{C}$, and ground to pass through a $0.2 \mathrm{~mm}$ sieve. The dried leaves were analyzed for total $\mathrm{N}$ by a Kjeldahl digestion method modified to recover $\mathrm{NO}_{3}-\mathrm{N}$, and steam distillation (Bremner and Mulvaney, 1982). Vernier calipers were used to measure tree girth $15 \mathrm{~cm}$ 


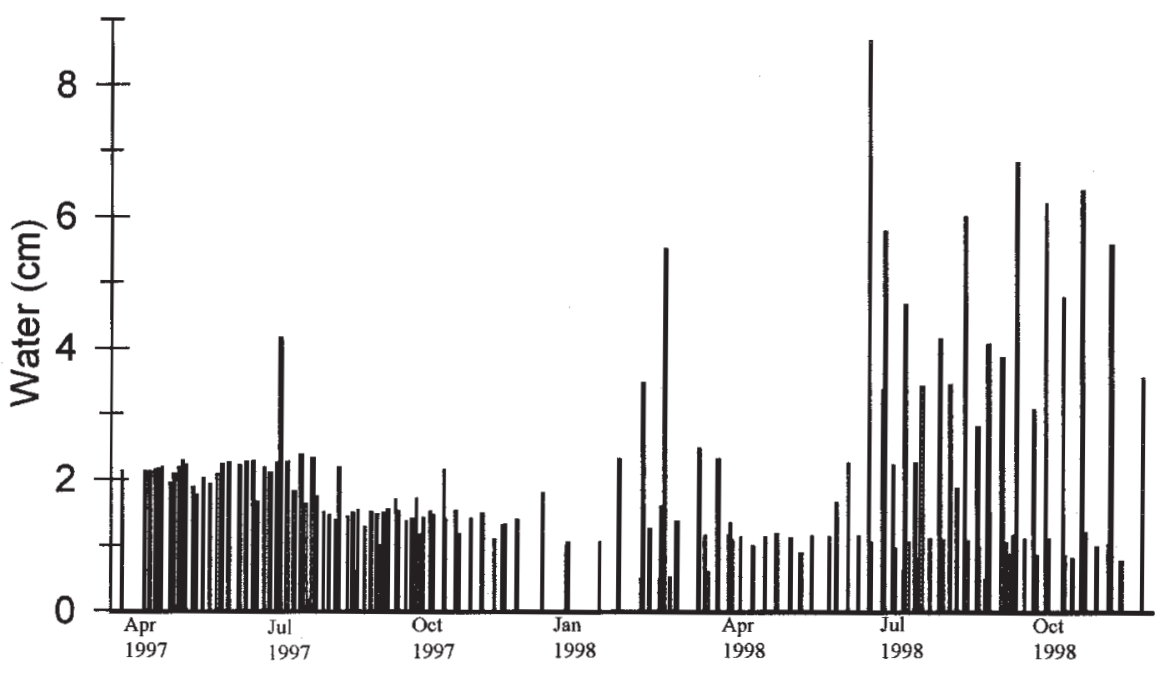

Fig. 1. Irrigation water applied from Apr. 1997 through Nov. 1998.

above the graft union in January, April, July, and October of each year.

Expt. 2. The second experiment was a randomized complete-block design with factorial combinations of three fertigation frequencies (weekly, monthly, and three times per year), two $\mathrm{N}$ fertilizer rates, and three replications for a total of 18 single-tree plots. The $\mathrm{N}$ rates were equivalent to the low and medium rates of Expt. 1 (Table 2). All $\mathrm{N}$ was applied as uniformly ${ }^{15} \mathrm{~N}$-labeled urea ammonium nitrate. Fertilizer was applied by hand with a spray bottle in a circular pattern within $0.6 \mathrm{~m}$ of the trunk. Irrigation was applied for $\geq 20$ min. immediately following fertilization to simulate fertigation.

As in Expt. 1, all trees used in Expt. 2 were planted in Mar. 1997. Eighteen trees received labeled $\mathrm{N}$ fertilizer during 1997 at the rates shown in Table 2. Fertigation began on 16 Mar. 1997 and ended 15 Nov. 1997. Fertigation was applied on the same dates as the corresponding treatments in Expt. 1. These 18 trees were destructively harvested in Dec. 1997. An additional 18 trees, which were also planted in Mar. 1997 and received unlabeled fertilizer during 1997, received labeled N during 1998. Fertigation began 1 Mar. 1998 and ended 1 Nov. 1998. Fertigation was applied on the same dates as the corresponding treatments in Expt. 1. These 18 trees were destructively harvested in Dec. 1998.

Table 1. Fertigation frequency and $\mathrm{N}$ rate treatments for navel oranges in Expt. 1.

\begin{tabular}{|c|c|c|c|}
\hline \multirow[b]{2}{*}{$\mathrm{N}$ rate } & \multirow{2}{*}{$\begin{array}{l}\text { Fertigation } \\
\text { frequency }\end{array}$} & \multicolumn{2}{|c|}{$\begin{array}{l}\text { Yearly cumulative } \\
\mathrm{N} \text { rates (g N/tree) }\end{array}$} \\
\hline & & 1997 & 1998 \\
\hline \multirow{4}{*}{ Low } & None & 0 & 0 \\
\hline & Weekly & 45 & 68 \\
\hline & Monthly & 45 & 68 \\
\hline & $3 \times /$ year & 45 & 68 \\
\hline \multirow[t]{3}{*}{ Medium } & Weekly & 90 & 136 \\
\hline & Monthly & 90 & 136 \\
\hline & $3 \times /$ year & 90 & 136 \\
\hline \multirow[t]{3}{*}{ High } & Weekly & 136 & 204 \\
\hline & Monthly & 136 & 204 \\
\hline & $3 \times /$ year & 136 & 204 \\
\hline
\end{tabular}

quency was accomplished by using the REG procedure in SAS.

\section{Results and Discussion}

Expt. 1. In Aug. 1997, leaf $\mathrm{N}$ in fertilized and unfertilized trees was $>25 \mathrm{mg} \cdot \mathrm{g}^{-1}$, which is a widely accepted "critical concentration" for mature citrus trees (Ludwick, 1990). There were no significant effects or interactions of $\mathrm{N}$ fertilizer rate or fertigation frequency on leaf $\mathrm{N}$ concentration (data not shown). Lack of citrus tree response to fertilizer $\mathrm{N}$ during the first year after planting has been reported by several researchers (Boman, 1993; Castle and Rouse, 1990; Swietlik, 1992). Lack of response to $\mathrm{N}$ has been attributed to mineralized soil organic $\mathrm{N}$, low weed competition, residual soil inorganic $\mathrm{N}$, and low tree $\mathrm{N}$ requirements (Boman, 1993; Castle and Rouse, 1990). However, residual soil inorganic $\mathrm{N}$, and presumably mineralized organic $\mathrm{N}$, were low in the current experiment. Swietlik (1992) found little response to $\mathrm{N}$ applied to young grapefruit trees during the first year after planting. He proposed that $\mathrm{N}$ furnished in the nursery may result in high tissue $\mathrm{N}$ concentrations and remobilization of this $\mathrm{N}$ may supply tree $\mathrm{N}$ needs during the first year after planting.

Leaf tissue N concentrations in Aug. 1998 were also $>25 \mathrm{mg} \cdot \mathrm{g}^{-1}$ in all fertilized and unfertilized trees (Fig. 2). Leaf $\mathrm{N}$ concentration in unfertilized trees was similar to that of 1997. Even though these trees had received no fertilizer $\mathrm{N}$ and were planted in soil containing low available $\mathrm{N}$, leaf tissue $\mathrm{N}$ concentrations remained high. Leaf tissue $\mathrm{N}$ concentration in fertilized plots in 1998 was higher than during 1997. Leaf tissue $\mathrm{N}$ was linearly correlated with $\mathrm{N}$ rate (Fig. 2). There were no significant effects of fertigation frequency on leaf $\mathrm{N}$ concentration; however, there was a trend of higher leaf $\mathrm{N}$ with increasing fertigation frequency at the medium and high $\mathrm{N}$ rates.

Other research on fertigation of young citrus has produced contradictory results. Koo (1980) reported no significant effects of fertilizer form or fertigation frequency on leaf $\mathrm{N}$ of bearing 'Valencia' oranges when fertilized with urea or fertigated with liquid $\mathrm{N}$ 3 or 10 times per year. Similarly, Ferguson et al. (1990) found no effect of fertigation frequency when 2-year-old tangerine trees were fertigated 6 to 32 times per year, at $\mathrm{N}$ rates of 220 to $550 \mathrm{~g} /$ tree. However, leaf $\mathrm{N}$ was significantly increased on young 'Hamlin' oranges when fertigated weekly compared with 5 split applications of granular fertilizer N (Willis and Davies, 1990). The different results among these studies illustrates the fact that the outcome of $\mathrm{N}$ management of young citrus trees may be particularly difficult to evaluate because results may take several seasons to realize (Gallasch, 1992). Du Sautoy (1992) noted that leaf tissue N does not always reflect $\mathrm{N}$ management.

Trunk diameter growth is related to tree canopy growth and can also reflect response to fertilizer N (Castle et al., 1994). There 
were no significant differences in any tree girth measurements during this study (data not shown). Tree growth may be more influenced by irrigation regime than by $\mathrm{N}$ management (Ferguson et al., 1990; Hilgeman, 1977; Koo and Hurner, 1969). Trunk girth increased by $\approx 50 \%$ between planting and Dec.1997. During the winter months, the trees showed little trunk growth. Between Mar. and May 1998, girth increased $\approx 30 \%$ and increased another $30 \%$ between May and Aug. 1998. Canopy volume and visual appearance of unfertilized trees were similar to those receiving fertilizer $\mathrm{N}$ throughout the study.

Leaf $\mathrm{N}$ concentration and trunk diameter of unfertilized trees indicated that the trees contained adequate $\mathrm{N}$ throughout the study. Leaf N in Aug. 1998 for unfertilized trees was significantly less than in fertilized trees, but still $>25 \mathrm{mg} \cdot \mathrm{g}^{-1}$. During this study, young citrus trees were slow to respond to $\mathrm{N}$ fertilizer management. Tree $\mathrm{N}$ reserves may have been remobilized for growth, thus limiting the effects of $\mathrm{N}$ fertilizer.

Expt. 2. Navel orange trees took up relatively little N during the 1997 season. The trees contained $\leq 6.6 \mathrm{~g} \mathrm{~N}$ when harvested in Dec. 1997, 9 months after planting (Table 3). In comparison, unplanted nursery trees contained $\approx 1.5 \mathrm{~g} \mathrm{~N}$ (data not shown). Therefore, seasonal uptake was $\leq 5 \mathrm{~g} \mathrm{~N}$. The low $\mathrm{N}$ uptake during the first year of growth explains the lack of response to $\mathrm{N}$ fertilizer observed in Expt. 1. Currently, recommended annual $\mathrm{N}$ rates for first-year citrus trees are 68 to $136 \mathrm{~g} /$ tree in Florida (Tucker et al., 1995), and 0 to $225 \mathrm{~g} /$ tree in Arizona, depending upon available soil N (Doerge et al., 1991).

There were few treatment effects on $\mathrm{N}$ uptake and partitioning during 1997, although $\mathrm{N}$ rate significantly affected $\mathrm{N}$ content (fertilizer and other) in stems. Stems, a N storage organ, contained $30 \%$ to $36 \%$ of the total tree $\mathrm{N}$ in the higher $\mathrm{N}$ plots. Lea-Cox and Syvertsen (1996) found that stems of 8-monthold greenhouse-grown citrus seedlings contained $4 \%$ to $18 \%$ of total tree N. However, Feigenbaum et al. (1987), working with bearing Shamouti oranges, found that stems contained between $42 \%$ and $44 \%$ of the $\mathrm{N}$ contained in the trees.

About $50 \%$ of the fertilizer $\mathrm{N}$ in the trees in Dec. 1997 was found in the leaves. However, this constituted $<3 \%$ of the fertilizer $\mathrm{N}$ applied to the trees. Leaf tissue $\mathrm{N}$ constitutes a large part of citrus $\mathrm{N}$ reserves. Lea-Cox and Syvertsen (1996) reported $33 \%$ to $47 \%$ of the total $\mathrm{N}$ taken up by citrus seedlings was in new growth, mostly leaf tissue. Wallace (1954) fertilized three year-old Washington navel oranges in California with ${ }^{15} \mathrm{~N}$ labeled $\mathrm{Ca}\left(\mathrm{NO}_{3}\right)_{2}$. Only $15 \%$ of the fertilizer $\mathrm{N}$ was located in the leaf tissue $65 \mathrm{~d}$ after fertilization. The majority of the leaf $\mathrm{N}$ had been remobilized from tree $\mathrm{N}$ reserves. In our study, $<3 \%$ of the fertilizer $\mathrm{N}$ applied was found in the leaves in Dec. 1997. However, fertilizer $\mathrm{N}$ comprised $\approx 50 \%$ of the total leaf $\mathrm{N}$ content.

Much of the N taken up during 1997 was derived from the fertilizer. However, fertilizer $\mathrm{N}$ uptake was $\leq 6 \%$ of that applied in any treatment. The primary reason for this low $\mathrm{N}$ fertilizer uptake was the slow rate of growth and low N requirement of the trees (Swietlik, 1992). Maust and Williamson (1994) reported that $\mathrm{N}$ use efficiencies were $48 \%$ to $70 \%$ when fertilizer $\mathrm{N}$ was applied to containerized citrus trees at concentrations of 12.5 to $200 \mathrm{mg} \cdot \mathrm{L}^{-1}$. The lack of tree response to fertilizer $\mathrm{N}$, and the low $\mathrm{N}$ use efficiency seen in our study suggest that $\mathrm{N}$ applications are not needed in the first year after planting for microsprinkler irrigated navel orange trees in desert growing regions.

Two-year-old trees that received nonlabeled fertilizer N during 1997 and labeled N during 1998 were harvested in Dec. 1998. There were few significant differences detected in fertilizer $\mathrm{N}$ content or partitioning between treatments (Table 4). The "other" N shown in Table 4 includes $\mathrm{N}$ contained in the trees at planting, $\mathrm{N}$ derived from soil and root-ball soil, $\mathrm{N}$ in irrigation water taken up from Jan. 1997 to Dec. 1998, and N fertilizer taken up during 1997. Fertilizer $\mathrm{N}$ found in the trees in Dec. 1998 was 13.5 to $19.6 \mathrm{~g} /$ tree, several times greater than in Dec. 1997. Total $\mathrm{N}$ from all sources was $32.2 \mathrm{~g} /$ tree in Dec. 1998, compared with $5.2 \mathrm{~g} /$ tree in Dec. 1997. This reflects the more rapid growth observed

Table 3. Nitrogen in navel orange trees at Dec.1997 harvest.

\begin{tabular}{|c|c|c|c|c|c|c|c|c|c|c|c|c|c|}
\hline \multirow{2}{*}{$\begin{array}{l}\text { N Rate } \\
\text { (g/tree) }\end{array}$} & \multirow{2}{*}{$\begin{array}{l}\text { Fertigation } \\
\text { frequency }\end{array}$} & \multicolumn{3}{|c|}{ Roots } & \multicolumn{3}{|c|}{ Stems } & \multicolumn{3}{|c|}{ Leaves } & \multicolumn{3}{|c|}{ Tree totals } \\
\hline & & Fertilizer & Other $^{2}$ & Total & Fertilizer & Other $^{2}$ & Total & Fertilizer & Other $^{2}$ & Total & Fertilizer & Other $^{2}$ & Total \\
\hline \multicolumn{14}{|c|}{ (g/tree) } \\
\hline \multirow{3}{*}{45} & Weekly & 0.6 & 0.9 & 1.5 & 0.6 & 0.8 & 1.4 & 1.2 & 1.1 & 2.3 & 2.4 & 2.8 & 5.2 \\
\hline & Monthly & 0.6 & 0.8 & 1.4 & 0.7 & 0.8 & 1.5 & 1.0 & 0.8 & 1.8 & 2.3 & 2.4 & 4.7 \\
\hline & $3 \times /$ year & 0.5 & 0.7 & 1.2 & 0.4 & 0.6 & 1.0 & 1.0 & 1.0 & 2.0 & 1.9 & 2.3 & 4.2 \\
\hline \multirow[t]{3}{*}{90} & Weekly & 0.9 & 1.1 & 2.0 & 0.9 & 1.0 & 1.9 & 1.3 & 1.0 & 2.3 & 3.1 & 3.1 & 6.2 \\
\hline & Monthly & 0.4 & 0.7 & 1.1 & 0.7 & 0.9 & 1.6 & 0.9 & 0.8 & 1.7 & 2.0 & 2.4 & 4.4 \\
\hline & $3 \times /$ year & 0.7 & 0.9 & 1.6 & 0.9 & 1.1 & 2.0 & 1.6 & 1.4 & 3.0 & 3.2 & 3.4 & 6.6 \\
\hline \multicolumn{14}{|c|}{ Significance } \\
\hline Replication & & NS & NS & $*$ & NS & NS & NS & NS & NS & NS & NS & NS & NS \\
\hline Frequency $(\mathrm{F})$ & & NS & NS & * & NS & NS & NS & NS & NS & NS & NS & NS & NS \\
\hline Nitrogen $(\mathrm{N})$ & & NS & NS & NS & ** & * & ** & NS & NS & NS & NS & NS & NS \\
\hline $\mathrm{F} \times \mathrm{N}$ interaction & & NS & NS & NS & NS & NS & NS & NS & NS & NS & NS & NS & NS \\
\hline
\end{tabular}

${ }^{\mathrm{z}}$ Other includes $\mathrm{N}$ from all nonfertilizer sources.

Ns, ${ }^{*},{ }^{* *}$ Nonsignificant or significant at $P=0.05$ and $P=0.01$, respectively.

Table 4. Nitrogen in navel orange trees at Dec.1998 harvest.

\begin{tabular}{|c|c|c|c|c|c|c|c|c|c|c|c|c|c|}
\hline \multirow{2}{*}{$\begin{array}{l}\begin{array}{l}\text { N Rate } \\
(\mathrm{g} / \text { tree })\end{array} \\
\end{array}$} & \multirow{2}{*}{$\begin{array}{l}\text { Fertigation } \\
\text { frequency }\end{array}$} & \multicolumn{3}{|c|}{ Roots } & \multicolumn{3}{|c|}{ Stems } & \multicolumn{3}{|c|}{ Leaves } & \multicolumn{3}{|c|}{ Tree totals } \\
\hline & & Fertilizer & Other $^{2}$ & Total & Fertilizer & Other $^{2}$ & Total & Fertilizer & Other $^{2}$ & Total & Fertilizer & Other $^{2}$ & Total \\
\hline \multicolumn{14}{|c|}{ (g/tree) } \\
\hline \multirow[t]{3}{*}{68} & Weekly & 2.0 & 2.3 & 4.3 & 3.7 & 4.3 & 8.0 & 10.3 & 10.1 & 20.4 & 16.0 & 16.7 & 32.7 \\
\hline & Monthly & 1.8 & 2.6 & 4.4 & 3.2 & 4.2 & 7.4 & 8.5 & 10.6 & 19.1 & 13.5 & 17.4 & 30.9 \\
\hline & $3 \times /$ year & 2.3 & 3.2 & 5.5 & 3.5 & 4.5 & 8.0 & 9.6 & 11.3 & 20.9 & 15.4 & 19.0 & 34.4 \\
\hline \multirow{3}{*}{136} & Weekly & 2.4 & 2.4 & 4.8 & 4.5 & 3.2 & 7.6 & 12.7 & 8.1 & 20.8 & 19.6 & 13.7 & 33.3 \\
\hline & Monthly & 2.4 & 2.9 & 5.3 & 3.6 & 4.3 & 7.9 & 11.2 & 11.9 & 23.1 & 17.2 & 19.1 & 36.3 \\
\hline & $3 \times /$ year & 1.6 & 1.8 & 3.4 & 4.0 & 3.6 & 7.6 & 9.2 & 8.0 & 17.2 & 14.8 & 13.4 & 28.2 \\
\hline \multicolumn{14}{|c|}{ Significance } \\
\hline Replication & & $* *$ & NS & NS & NS & NS & NS & NS & NS & NS & NS & NS & NS \\
\hline Frequency $(\mathrm{F})$ & & NS & NS & NS & NS & NS & NS & NS & NS & NS & NS & NS & NS \\
\hline Nitrogen $(\mathrm{N})$ & & NS & NS & NS & NS & NS & NS & NS & NS & NS & NS & NS & NS \\
\hline $\mathrm{F} \times \mathrm{N}$ interaction & & $*$ & NS & NS & NS & NS & NS & NS & NS & NS & NS & NS & NS \\
\hline
\end{tabular}

${ }^{2}$ Other includes $\mathrm{N}$ from all nonfertilizer sources.

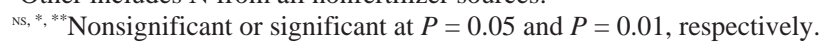




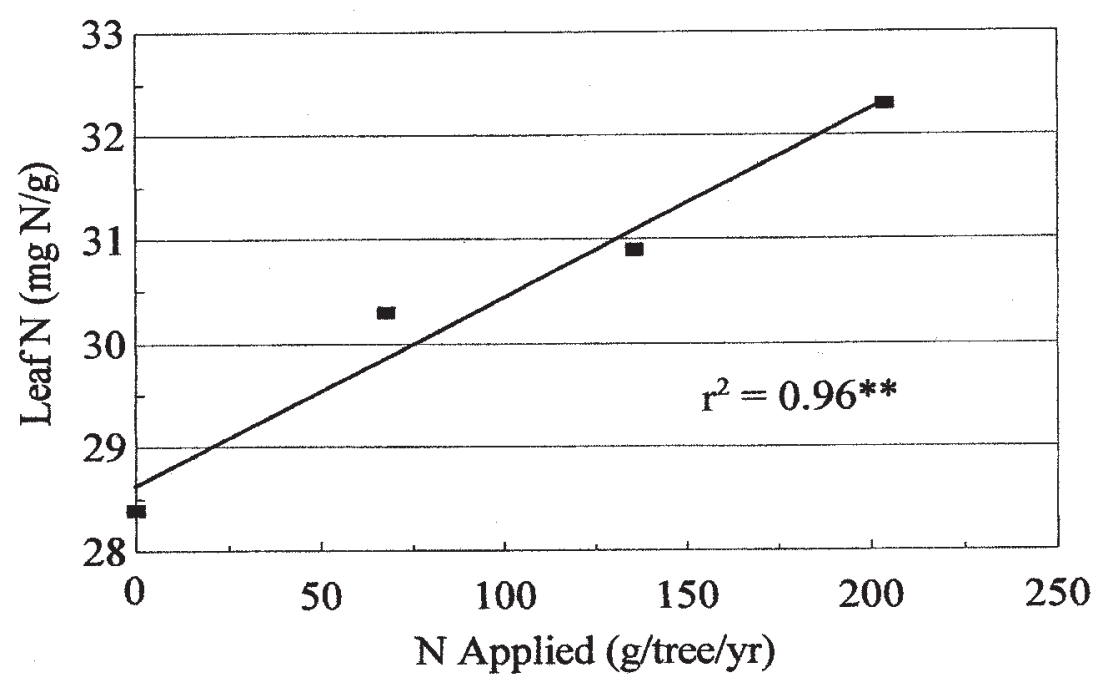

Fig. 2. Regression of leaf $\mathrm{N}$ concentration and fertilizer N applied from tissue collected in Aug. 1998 for young navel oranges. Points represent treatment means.

during 1998. However, in no case was $\mathrm{N}$ fertilizer uptake $>25 \%$ of that applied. The $\mathrm{N}$ rates applied during 1998 were still considerably in excess of that needed by the trees.

The average $\mathrm{N}$ content of roots, stems, and leaves was 4.6, 7.7, and $20.5 \mathrm{~g} /$ tree, respectively, in Dec. 1998, with fertilizer N contributing $\approx 50 \%$ (roots, stems, and leaves averaged 2.1, 3.7, and $10.2 \mathrm{~g} /$ tree, respectively). Leaf tissue harvested in Dec. 1998 contained $>60 \%$ of the fertilizer $\mathrm{N}$ taken up by the trees. This result contrasts with those from a study of 1year-old containerized citrus in which only $22 \%$ of leaf $\mathrm{N}$ was derived from fertilizer applications and $78 \%$ from tree $\mathrm{N}$ reserves (Maust and Williamson, 1994). Fertilizer N contained in stems in Dec. 1998 was almost two-fold greater than in the roots. Lower amounts of $\mathrm{N}$ contained in the roots compared to shoots may reflect favorable growing conditions of ample water and N supply (Feigenbaum et al., 1987; Ford et al., 1957). Despite the greater fertilizer $\mathrm{N}$ recovery during 1998 , no response of trunk growth to fertilizer $\mathrm{N}$ was observed. Similar to Expt. 1 (Fig. 2), leaf N concentrations in 1998 were lower for unfertilized trees than for fertilized trees. Nevertheless, leaf $\mathrm{N}$ in the unfertilized trees remained well above the assumed "critical level" for optimal tree growth. These results suggest that optimum $\mathrm{N}$ rates for microsprinkler irrigated citrus in the desert Southwest are much lower than current recommendations (Doerge et al., 1991).

\section{Conclusions}

Nitrogen content of navel orange trees planted in Mar. 1997 was $\approx 1.5 \mathrm{~g} /$ tree. The trees did not respond to $\mathrm{N}$ rate or fertigation frequency during 1997. In Dec. 1997, the trees contained 1.9 to $3.2 \mathrm{~g} \mathrm{~N}$, which was $<6 \%$ of the
$\mathrm{N}$ fertilizer applied during 1997. Leaf tissue contained $\approx 50 \%$ of fertilizer $\mathrm{N}$ found in the trees. Leaf $\mathrm{N}$ was not affected by $\mathrm{N}$ rate or fertigation frequency and was above the critical $\mathrm{N}$ concentration $\left(25 \mathrm{mg} \cdot \mathrm{g}^{-1}\right)$ in all trees. Unfertilized trees showed similar growth and leaf $\mathrm{N}$ concentration as fertilized trees. In Dec. 1998 , trees contained 13.5 to $19.6 \mathrm{~g} \mathrm{~N}$, which was $<25 \%$ of the fertilizer $\mathrm{N}$ applied during 1998. Again, leaf $\mathrm{N}$ concentration remained above $25 \mathrm{mg} \cdot \mathrm{g}^{-1}$ in all plots. However, leaf $\mathrm{N}$ concentrations declined in unfertilized trees and increased in fertilized trees during 1998. Leaf $\mathrm{N}$ was linearly related to $\mathrm{N}$ rate, but was unaffected by fertigation frequency. Our results suggest that $\mathrm{N}$ applications are not needed during the first growing season after planting for microsprinkler irrigated citrus trees in Arizona. Modest rates of $\mathrm{N}$ application may be needed during the second growing season to maintain adequate tree $\mathrm{N}$ reserves.

\section{Literature Cited}

Boman, B.J. 1993. First-year response of 'Ruby Red' grapefruit on four rootstocks to fertilization and salinity. Proc. Fla. State Hort. Soc. 106:12-18.

Boman, B.J. 1996. Fertigation versus conventional fertilization of flatwoods grapefruit. Fert. Res. 44:123-128.

Bremner, J.M. and C.S. Mulvaney. 1982. NitrogenTotal. p. 595-624. In: A.L. Page et al.(eds.). Methods of soil analysis. Part II: Chemical and microbiological properties. Amer. Soc. Agron., Madison, Wisc.

Castle, W.S. and R.E. Rouse. 1990. Total mineral nutrient content of Florida citrus nursery plants. Proc. Fla. State Hort. Soc. 103:42-43.

Castle, J.R. A.L. Lidon, C. Ginestar, and C. Ramos. 1994. Yield growth and nitrate leaching in dripirrigated citrus trees under different fertigation treatments. p. 961-968. In: J.W. Worthington (ed.). Microirrigation for fruit crops. Southern Regional Project S-143.

Du Sautoy, N. 1992. Field trial evaluation of 'Valencia' fruiting terminal leaf $\mathrm{P}, \mathrm{K}$, and $\mathrm{Mg}$ norms for a low base loamy sand. Proc. Intl. Soc. Citricult. 2:547-550.

Doerge, T.A., R.L. Roth, and B.R. Gardner. 1991. Nitrogen fertilizer management in Arizona. Univ. of Arizona. College of Agr., Rpt. no. 191025.

Feigenbaum, S, H. Bielorai, Y. Erner, and S. Dasberg. 1987. The fate of ${ }^{15} \mathrm{~N}$ labeled nitrogen applied to mature citrus trees. Plant Soil 97:179-187.

Ferguson, J.J., F.S. Davies, and J.M. Bulger. 1990. Fertigation and growth of young 'Sunburst' tangerine trees. Proc. Fla. State Hort. Soc. 103:89.

Ford, H.W., W. Reuther, and P.F. Smith. 1957. Effect of nitrogen on root development of 'Valencia' orange trees. J. Amer. Soc. Hort. Sci. 70:237-244.

Gallasch, P.T. 1992. The use in southern Australia of citrus leaf analysis to develop more efficient fertilizer programs. Proc. Intl. Soc. Citricult. 560-563.

Hilgeman, R.H. 1977. Response of citrus trees to water stress in Arizona. Proc. Intl. Soc. Citricult. 1:70-74.

Koo, C.J. and G.T. Hurner. 1969. Irrigation requirements of citrus grown on Lakewood fine sand. Proc. Fla. State Hort. Soc. 82:69-72.

Koo, C.J. 1980. Results of citrus fertigation studies. Proc. Fla. State Hort. Soc. 93:33-36.

Lea-Cox, J.D. and J.P Syvertsen. 1996. How nitrogen supply affects growth and nitrogen uptake, use efficiency, and loss from citrus seedlings. J. Amer. Soc. Hort. Sci. 121:105-114.

Ludwick, Albert (ed.). 1990. Western fertilizer handbook: Horticulture edition. Interstate Publishers, Danville, Ill.

Maust. B.E. and J.G. Williamson. 1994. Nitrogen nutrition of containerized citrus nursery plants. J. Amer. Soc. Hort. Sci. 119:195-201.

Marler, T.E and F.S. Davies. 1990. Microsprinkler irrigation and growth of young 'Hamlin' orange trees. J. Am. Soc. Hort. Sci. 115:45-51.

Mulvaney, R.L. 1993. Mass spectrometery, p. 1157. In: Roger Knowles and T. Henry Blackburn (eds.). Nitrogen isotope techniques. Academic, San Diego.

Sanchez, C.A., A.M. Blackmer, R. Horton, and D.R. Timmons. 1987. Assessment of errors associated with plot size and lateral movement of nitrogen-15 when studying fertilizer recovery under field conditions. Soil Sci. 144:344-351.

SAS Institute. 1999. SAS user's guide. SAS Inst., Cary, N.C.

Swietlik, D. 1992. Yield, growth and mineral nutrition of young 'Ray Ruby' grapefruit under trickle or flood irrigation and various nitrogen rates. J. Amer. Soc. Hort. Sci. 117:22-27.

Tucker, D.P., A.K. Alva, L.K. Jackson, and T.A. Wheaton. 1995. Nutrition of Florida citrus trees. Univ. Fla. Coop. Ext. Serv. SP 169.

Wallace, A. 1954. Ammonium and nitrate nitrogen absorption by Citrus. Soil Sci. 78:89-94.

Willis, L.E. and F.S. Davies. 1990. Fertilization, nitrogen leaching and growth of young 'Hamlin' orange trees on two rootstocks. Proc. Fla. State Hort. Soc. 103:30-37.

Willis, L,E., F.S. Davies, and D.A Graetz. 1991. Fertigation and growth of young 'Hamlin' orange trees in Florida. HortScience 26:106-109. 